\title{
ADVANTAGES AND DISADVANTAGES OF KAZAKH ANIMATION
}

\author{
Myrzabek Nasipkhanul
}

\section{ABSTARCT}

This article analyzes the history and development of Kazakh animation. What is the effect of foreign animation on children? The story of the development and stagnation of our animation. Here's a brief look at how the Kazakh animation can outperform others. The animators will be given brief suggestions.

Keywords: Amen Kaidar, Cartoon, Art, History, Kazakhstan, Painting, Children, The future.

\section{INTRODUCTION}

We need to pay attention to the moment when children are in a flock, and the future of such a huge Kazakhstan-like country is locked up tomorrow. In 1967, when Amen Kaidar made his cartoon debut, Kamal Smailov, the then head of the Kazakhfilm studio, supported it. By that time, the cartoon was sent to Moscow for reporting. However, the head of the Kazakhfilm studio in Moscow, Yugedi, disbelieved in the big-group work. However, after giving his courage, Kalmal Smailov arrived in Moscow and checked out.

While independent Kazakhstan is in power, children of the Kazakh nation, who are rich in legends and legends, cannot succumb to cartoons in their own language or tradition. More than half a century has passed in the foregoing events. In this article, we will look at the future of blurry cartoon children.

\section{METHODS}

The methods used in this study are comparatively analytical. The ideas about Kazakh animation are complemented and substantiated.

\section{The advent of the Kazakh animation}

As the human race grows, so do the values and values of art. But the ancient rock carvings and archeological excavations still amaze the scientists and art people of today. Looking at them, we can see that human civilization and art have never lost their place in harmony with the human soul. Many of these ancient relics speak to us as paintings. These mysterious paintings tell us 
International Journal of Arts and Humanities

ISSN: 2581-3102

Volume: 04, Issue: 05 "May 2020"

centuries-old history. These days, he has moved on to painting and built a new cartoon called Humanity. The art is already at a higher level because it is directly related to the future of the children.

Generally speaking, the grandfather of many collections is a picture. The fine art of Kazakh art originates from Shokan Ualikhanov and Abilkhan Kasteev. And in Kazakh, the grandfather of the animated work, Amen Kaidar, who animated the same art.

Drawing by Amen Kaidarov in 1967, based on a folk tale, the first colorful "Why Swallow's Swallow's Tail?" A cartoon has been made In addition to Kazakh folk music, the Kazakh dombra sounded beautifully in the film. It has been shown in 48 countries since its launch and has been a buzz in the arts. At the All-Union Film Festival in Leningrad (now St. Petersburg) (1968), the 1975 New York International Film Festival, he won the Bronze Praksinoscope. Obviously, this work, which requires a lot of work, came to us with great success. Let's review the progress we have made in this half century.

For a moment, the Kazakh animation is in a state of stagnation. He was often featured in periodicals. In an interview with Aikyn newspaper, Kazakh animation's grandfather Amen Caidar Seysen Amirbekuly told "There is no Kazakh cinema or blue screen for children." This is the story that has ended. Honestly, now I have no hope or hope. I myself, myself, dwell on the cartoon industry of the country, "criticizes the current state of the art. In this article "You Need to Care for Kazakh Animation," Seisen Amirbekovich also made a serious statement: "The western part of the boom of globalization."

the young generation of animation, cruelty, or fraud in the animation? If we want our children to grow up to be kind, affectionate, compassionate, patriotic, and courageous, should we not have a lot of folklore, which is inherited from grandfather to great-grandfather? Of great educational importance, how many fairy tales and legends do we have? Isn't there anyone who can use them?"

Similar articles have been published back and forth and have been a cause for concern since the beginning of Kazakh animation.

\section{Development of Kazakh animation}

The cartoon "Koshkar and Tekhe", shot by "Sak-Zhebe" movie studio, has given a new impetus to Kazakhstan. This short film has attracted a lot of thought and action. Newspaper headlines, "Where is the Kazakh animation?", Now proudly start writing "rams and goats." "Ana Tili" Newspaper, published on April 3, 2013, on the eve of the Nauryz Holiday JSC "Kazakhfilm" named after Sh. Aimanov made a great gift for the children. The Kazakh cartoon, based on the 
International Journal of Arts and Humanities

ISSN: 2581-3102

Volume: 04, Issue: 05 "May 2020"

fairy tale "Ertostik", went to the audience for the first ever full-length animated film "Ertostik and the Dragon". Little children can now see Kazakh fairytale characters in 3D. " The directors of this division were Jaken Danenov and Rustam Turaliev. This is how the short Kazakh animation has come to an end.

From here, the Sak Film Studio has launched a 2016 full-length filming of Batyrkhan Daurenbekov's 76-minute film “ Kazakh Eli ", a 60-minute film by Adai Abilda in 2018, a 2018 Kazakhfilm Studio named after Sh. A full-length animated feature film "Muzbalak" was shot. Looking at the general stages of development of the Kazakh animation, there was a slight stagnation, but it was not lost. Elderly people, such as Amen and Kaydar, worked hard to bring up disciples in the field. That hope turned into a young, flaming youth of animation, the scourge of animation.

The Muzbalak branch, which was released in July 2018, has been attracting the public since its launch. It has been shown to cinemas in 9 major cities of the country. At the same time

Best animated film in the country - Kulager-2018 Director Turdibek Maidan was nominated for Best Director in the State Pride 2018 contest, organized by the Astana Film Academy. After that, the town participated in numerous film festivals and won prizes. Announced in France, recently participated in the Annecy Animated Film Festival and brought unprecedented breakthroughs in the history of Kazakh animation. He also participated in the "With the Family" festival in Yaroslavl, Russia this year, and was awarded a "Special Jury Prize". At the 24th Schlingel International Children and Youth Film Festival in Chemnitz, Germany, from October 7 to October 13, this year. was awarded by the Animated Film Institute (DIAF). On December 2-5, the Israeli International Film Festival "Near Nazareth Festival" was again nominated for "Best Animated Film". What is the secret of the Muzbalak branch getting so many titles so far from the animated films?

\section{Analysis of the branch "Muzbalak"}

The criticisms that have been said so far, state that at any moment in the field of art we can only surpass ourselves by our own values. So what is the benefit of this film? Famous folklorist and ethnographer Bolat Bopaiul wrote in a 20x 2018 article on the Whip site a historical, scientific, and artistic work published after the animated film, Muzbalak, in Kazakhstan History. "Muzbalak" - fairy tale, legendary consciousness; Religious consciousness; from the history to the scientific consciousness, the five unconscious minds that have been created today have been integrated into the story line from the beginning to the end of the filament. These five different ways of thinking - visual, fantastic, logical, psychological, metaphysical - penetrated the 
International Journal of Arts and Humanities

ISSN: 2581-3102

Volume: 04, Issue: 05 "May 2020"

mysteries of open and hidden thoughts in the souls of the big, small, positive and unpleasant characters in the film, and opened the character's character in front of the viewer."

The guys, who were focused on the fate of the eagle, made a great stir. The script is written by Erbol

Boranshyevich, Turdibek Maidanovich, Tlek Tuleugazyevich, Aday Kunanbayevich Abildinov. The directors, Turdibek Maidanuly, Tlek Tugagazyuly, fully understand the weight of the theme they are talking about, can be seen in the full-length animation "Ice Ball". By the way, the level of professionalism, the computer graphics system is consistent and convincing. I am glad that the Kazakh nationality was shown without breaking his attitude.

The branch is not subject to a specific time period. No one could say for sure when the bird was first launched. Such periods would, in many sections, be manifested in the same manifestation of bare-fleshed leaves, or of fur hides. And on the glacier, everything is different, the Kazakh life, the gloomy look. Significant events. It is also a successful impetus for Kazakh civilization to be noticed by children.

With the onset of the event, he is drawn to himself.

There are a lot of monsters and sculptures still alive in human cinema today. But in most of those fantasy scenes we know, in the blood-raising monster, only the bad-hearted people in the place would come to enmity, and the "iceberg" dragon was taken as the enemy of all mankind. He does not distinguish between good and bad. The loss of his sight is the result of the shamelessness of the human soul. Here is the way out, no help. Who saves.

Another plagiarism, when a village crowed and ran wild, the country-led heroes marched against a village. But the inner serpent woke up, and the evil intentions filled the noble mind with dust. The last thread that struck the dragon was broken. The hope of the country, the man's breath is gone. People have sometimes made a clear appearance for the sake of their own self, in a plot to sell the black forest population. It was a milestone in the history of Kazakhstan. At such moments, they always fall and fall. Who was it that rode on such a white horse, put his soul on a cloth, and was swallowed up by a dragon? The bearded bear, as well as the Ospan-like male saiga, born in the garden of his people, is drawn to our eyes. He was also a stranger to those who were shaking hands and feet. What a harmonious match. In the history of Kazakhstan there are many white heroes, dead white horses, dead in the middle of their dreams.

Generally, in the Turdibek's "Sword" and Tilek's "Stone Master," co-authored, there is a dragon. Everybody has a monster that just goes out of its memory and is told in legends. Each nation understands in its own way. And these guys brought the dragon closer to the Kazakhs as the 
International Journal of Arts and Humanities

ISSN: 2581-3102

Volume: 04, Issue: 05 "May 2020"

Buryats. There, perhaps, they were plunged into the fate of the nation. And I am in touch with the truth. According to legends, the dragon, approaching the destruction of the earth, accepted the wishes of all the supplicants, and commanded him to go to the iceberg. Then he spent three nights in the iceberg. During the first night, the yen landed smoothly, and the second night, the camel grazed and ate a drooling borax, which was eaten by a borah. Thus, he spent three nights on a three-carat earth, and he climbed into the ice, frozen in ice. Now it will come out of this lock, in the last days. In the February frosts, the bourgeoisie whose white foam swooped in his mouth, what might he have thought in one example of a dragon? However, these guys have explored the Kazakh legends and presented it to the people as a wonderful work. The video reads Mukagali's words: "I will return the poetic Kazakh song in black and white."

Thirdly, the eagle captivates a man in the process of raising his son. The mother-in-law is like a white eagle, a mother of a white eagle, who guides and guides her son. The gestures are lively and vibrant. The carcass is shot over the clouds, over a cloud, at the beginning of a steep summit, with a sledgehammer. Great for Filmy's language purity. The phrase "old-fashioned dog will not be quenched" is spoken to Aktay by shouting to Aktau. Many of these rational words have been used.

Talking with the demon, the scary word of the ghostly shepherd awakens the country and seeks a savior. As the days go, the sign with the staff of the stick will be opened with the country. The eagle caught in a thousand rounds is not easy. The squirrel's kneeling kneeling command is to tear the country down, not to go with the sky. But the kindness in his heart prevailed. It looks as if the bear was looking at the rolling bear on the front of the yurta, and the shackle of the Sahara. A sharp moment in Aktai's hands, who tore his left skin, and the scorching rays of the sun, can ruin your soul. Friendship, fear and hope swept through the walls, and finally the desire of the country came true. There are many details in each painting. Cold stools are accompanied by scallop. He was like a locust's soul. When the wishes of the people were justified, the dragon landed, and the eagle and the eagle reached the ideal, the lively flower returned to spring.

This section made us think a little bit. Let's compare the full-length movie with the film "The Tale of the Fairytale and the Dragon". Both are legendary. However, the fairy tale of folklore was distorted and different characters appeared in Irtysh. At times, the characters in Greek legends feel as if they are cold. Such memorable events have a great impact on the beauty of the film and fail to achieve the director's goal. That is why the future of Kazakh animation is ahead if we continue to embark on the work done by Amen Kaidar and present our children with valuable treasures as well as in the Muzbalak. 


\section{CONCLUSION}

Summing up the article, we will dwell on the following conclusion. Several factors influenced the development of Kazakh animation. The support of the state. Financial aid. He is also the second pure professional. Third national values. Undoubtedly, the film, which focuses on national values, will gain its status without losing its place.

When the foreign branch is distracted by the child, the boy's hopes for tomorrow and the future of the Kazakhs weaken. The truth is that a child who is not brought up by his or her own knowledge will always be happy to be around. If we think that we will uphold the honor of Kazakhstan at any time and illuminate the future, then we should pay attention to the future of our children.

\section{REFERENCES}

Gaukhar Aspandiyarovna The newspaper "Kazakh uni". March 6, 2012 "Where is the Kazakh animation?"

Anar Duisenbayevna Newspaper "Ana tili". March 28, 2013 "What is the effect of cartoons on child rearing?"

Gulmira Aimaganbet "Almaty Akshamy" Newspaper. "The present and future of national animation."

Website "Kamshy"

The newspaper "Ush Kongyr" 